\title{
0-2 yaş çocuklarda beslenme alışkanlıklarının değerlendirilmesi: Çok merkezli çalışma
}

\author{
Evaluation of eating habits in children 0-2 years of age: a multicenter study
}

\author{
Raziye Şule Gümüştakım ${ }^{1}$, Hilal Deşik Aksoy ${ }^{2}$, Saide Eda Cebeci ${ }^{3}$, Serdal Kanuncu ${ }^{4}$, Lütfullah Çakır ${ }^{5}$, Erdinç \\ Yavuz $^{6}$
}

${ }^{1}$ Osmaniye Merkez 3 Nolu Cumhuriyet Aile Sağlığı Merkezi, Osmaniye, Türkiye

${ }^{2}$ Pelitlibağ Aile Sağlığı Merkezi, Denizli, Türkiye

${ }^{3}$ Serdivan Aile Sağlığı Merkezi, Sakarya, Türkiye

${ }^{4}$ Tanışma Aile Sağlığı Merkezi, Hatay, Türkiye

${ }^{5}$ Aile Hekimliği Ana Bilim Dalı, Tıp Fakültesi, Ordu Üniversitesi, Ordu, Türkiye

${ }^{6}$ Aile Hekimliği Kliniği, Samsun Eğitim ve Araştırma Hastanesi, Samsun, Türkiye

\section{ÖZET}

Giriş: Dünya Sağlık Örgütü (WHO) ve Birleşmiş Milletler Çocuklara Yardım Fonu (UNICEF), 6. ayda ek besinlere başlayarak emzirmenin 2 yaşına kadar sürdürülmesini önermektedir. Çalışmamızdaki amacımız 0-2 yaş arası çocuklardaki beslenme alışkanlıklarını ve annelerinin beslenme konusundaki bilgi düzeylerini değerlendirmektir.

Yöntem: Tanımlayıcı nitelikteki bu çalışmaya 0-2 yaş bebeği olan toplam 250 anne dahil edildi. Annelere, sosyodemografik özelliklerin, anne sütünün, ek besinlerin ve bu konularda annelerin bilgi düzeyinin değerlendirildiği bir anket formu verildi. Ardından bebeklerin boy-kilo ölçümleri yapıldı. Araştırmadan elde edilen veriler SPSS 16,0 istatistik programı kullanılarak değerlendirildi, istatistiksel analizlerde tanımlayıcı analizler ve ki-kare testi kullanıldı. $\mathrm{p}<0,05$ anlamlılık sınırı olarak kabul edildi.

Bulgular: Bebeklerin \%84,3’ü ilk 1 saat içinde anne sütü almıştır. \%41.3'ü 3-6 ay arası anne sütü alırken, \%16,5'inde 6 aydan önce anne sütü kesilmiştir. Bebeklerin \%50,8'i mama ile beslenmiş, \%49,2'sine ise biberon verilmiştir. Bebeklerin \%25,6'sına 6 aydan önce, $\% 51,2$ 'sine ise 6 aydan sonra ek gıda başlanmıştır. Anne eğitimi ile anne sütü hakkında bilgi, ek gıda hakkında bilgi, anne sütü kesilme zamanı ve bebek kilo persentili arasında fark bulunmuştur.

Sonuç: Annelerin anne sütü ve tamamlayıcı beslenme konusundaki bilgi düzeyleri ne kadar iyi olursa toplumun da bilgi düzeyi o kadar artı̧̧ gösterecek ve davranışlarına yansıyacaktır.

Anahtar kelimeler: Beslenme, anne sütü, emzirme

\begin{abstract}
Introduction: The World Health Organization (WHO) and United Nations Children's Fund (UNICEF) proposes that complementary food must be given starting from the 6th month and breastfeeding must continue until the age of 2 . The objective of our study was to assess dietary habits in children aged between 0 and 2 years and to assess the knowledge level about nutrition in their mothers.

Methods: 250 mothers who have children between the age of 0 and 2 were included in this descriptive study. Questionnaires which evaluate sociodemographic factors, breastfeeding, complementary nutrition and the knowledge level of mothers about these issues were given to the participants. Then length and weight measurements of infants were done. The data obtained from this study were analyzed using SPSS 16.0 statistical software. Descriptive analysis and chi-square test was used for statistical analysis. Statistical significance level was accepted as $\mathrm{p}<0.05$.

Results: $84.3 \%$ of babies were breastfed within the first hour. While $41.3 \%$ of them were breastfed between 3 and 6 months, breastfeeding was stopped in $16.5 \%$ of babies before 6th months. $50.8 \%$ of infants were fed with Formula and $49.2 \%$ of infants were fed with baby bottle. Supplementary food was started in the first six months to the $25.6 \%$ of babies and to $51.2 \%$ of them supplementary food was started after 6 months. Difference was found between training of mother and the knowledge about breastfeeding, knowledge about supplementary food, time for breastfeeding stop and infant weight percentile.

Conclusion: Society's knowledge level should increase and together with the increasing knowledge level of mothers on breast milk and complementary nutrition, a behavior oriented change would be observed.

Keywords: Nutrition, "milk, human", breast feeding
\end{abstract}

Başvuru / Submission: Haziran / June 24, 2016

Kabul / Acceptance: Ocak / Jan 17, 2017

Yazışma / Correspondence: Uzm.Dr.R.Şule Gümüştakım, 3 Nolu Cumhuriyet Aile Sağlığı Merkezi, Rızaiye Mah. 10045 sok. Merkez, Osmaniye, Türkiye

E-mail: sulesu82@mynet.com

Atıf / Cite: Gümüştakım RŞ, Aksoy HD, Cebeci SE, Kanuncu S, Çakır L, Yavuz E. 0-2 yaş çocuklarda beslenme alışkanlıklarının değerlendirilmesi: Çok merkezli çalışma. Fam Pract Palliat Care. 2017;2(1):1-8 


\section{GíRiș}

Sağlıklı yaşamın temellerinin atıldığı dönem olan hayatın ilk bir kaç yılı çok önemli bir dönem olmakla beraber bu kritik dönemde çocuğun yaşamı ve sağlıklı gelişimi için bazı biyolojik ve psikososyal gereksinimleri karşılanmalıdır. $\mathrm{Bu}$ açıdan çocuğun tüm gereksinimlerini karşılayan anne sütü en uygun besindir (1). Dünya Sağlık Örgütü (WHO) ve Birleşmiş Milletler Çocuklara Yardım Fonu (UNICEF), 6. ayda ek besinlere başlayarak emzirmenin 2 yaşına kadar sürdürülmesini önermektedir (2). Altı aydan sonra bebeğin besin öğesi gereksinimlerini karşılama konusunda anne sütü yetersiz kalmakta olup bazı ek gıdalar yavaş yavaş eklenerek bebeğin anne sütü ile beslenmeden erişkin tip beslenme dönemine sorunsuz olarak geçmesi sağlanmalıdır. Bebeğe verilen besinler, anne sütünün yanında destekleyici olarak verilmelidir (3). Yani anne sütünün yerine verilmesi amaçlanmaz. Altıncı ayda uygun ve yeterli ek gıdanın yanında anne sütüne devam etmek; altı ayından sonra çocuk için önemli bir besin, sıvı ve immünolojik koruma kaynağı olması açısından önemlidir (4, 5). Ek gidalara erken başlanması anne sütünün giderek azalmasına ve çocuğun kendisini enfeksiyonlardan koruyan bu doğal besinden yoksun kalmasına ve ishal oluşumunun kolaylaşmasına sebep olur $(6,7)$. Tamamlayııı besinlere zamanında geçilmesi ile 1sırma, çiğneme becerilerinin gelişiminin sağlanması, farklı tat ve yapıda besine alıştırılması mümkün olur. Beslenme çocuğun immün sistem, santral sinir sistemi ve endokrin sistem gibi tüm sistemlerin gelişiminde rol oynar (8).

Çalışmamızdaki amacımız 0-2 yaş arası çocuklardaki beslenme alışkanlıklarını ve annelerinin beslenme konusundaki bilgi düzeylerini değerlendirmektir.

\section{YÖNTEM}

Kesitsel tanımlayıcı tipte olan araştırmanın etik kurulu Karaman Halk Sağlığ1 Müdürlüğü'nden (12.05.2014 tarihli/3715 sayı numaralı) alınmış olup araştırma evreni 2014 yılı Ağustos ve Eylül ayları arasında Türkiye'nin 5 farklı ilindeki (Sakarya, Hatay, Karaman, Ordu, Rize) Aile Sağlığı Merkezlerine çeşitli nedenlerle başvuran 0-2 yaş bebeği olan toplam 250 anneyi kapsamaktadır.

Örneklem hesaplama yöntemiyle her aile hekiminin nüfusunda kayıtlı 100 bebeği olduğu düşünülerek $\% 5$ hata payıyla ve \%95 güven aralığında evren büyüklüğü 500, örneklem büyüklüğü ise 218 kişi olarak hesaplanmış olup toplanacak hasta sayısı 250 olarak öngörüldü. Verileri eksik olan 8 bebek çalışma dışı bırakıldı.

Çalışmaya katılmayı kabul eden annelere, 37 sorudan oluşan sosyodemografik özelliklerin, anne sütünün, ek besinlerin ve bu konularda annelerin bilgi düzeyinin değerlendirildiği bir anket formu verildi. Anketlerin bir kısmını annelerin kendisi doldurdu, soruları anlamakta zorlanan annelere ise yardımcı sağlık personeli tarafindan formun doldurulmasında yardımcı olundu. Ardından bebeklerin boykilo ölçümleri yapıldı. Boy-kilo ölçümleri çalışmaya katılan her aile sağlığı merkezinin kendi malzemeleriyle yapıldı ve belli bir standardizasyon uygulanmadi.

\section{İstatistiksel Analiz}

Araştırmadan elde edilen veriler SPSS 16,0 (SPSS Inc, Chicago, Illinois) istatistik programı kullanılarak değerlendirildi. İstatistiksel analizlerde tanımlayıcı özellikler, ki-kare testi ve Bonferonni düzeltmeli one way ANOVA kullanıldı. Sayısal değerler sürekli ve kesikli numerik değerler biçiminde ve yüzdelerle belirtildi. Sonuçlar \%95 güven aralığında, $\mathrm{p}<0,05$ anlamlılık düzeyinde değerlendirildi.

\section{BULGULAR}

Verilerimizin tamamı normal dağılıma uymakla birlikte araştırmaya katılmayı kabul eden 242 annenin yaş ortalaması $28,9 \pm 5,8$ (17-46 yaş) y1l olup sosyodemografik özelliklerin dağılımı Tablo 1'de verilmiştir.

Tablo 1. Sosyodemografik özelliklerin dağılımı

\begin{tabular}{|c|c|}
\hline Sosyodemografik özellikler & n (\%) \\
\hline \multicolumn{2}{|l|}{ Anne eğitimi } \\
\hline İlkokul & $73(\% 30,2)$ \\
\hline Ortaokul & $44(\% 18,2)$ \\
\hline Lise & $66(\% 27,3)$ \\
\hline Üniversite & $57(\% 23,6)$ \\
\hline Okuma-yazma yok & $2(\% 0,8)$ \\
\hline \multicolumn{2}{|l|}{ Anne mesleği } \\
\hline Ev hanımı & $184(\% 76,0)$ \\
\hline Memur & $44(\% 18,2)$ \\
\hline Serbest meslek & $14(\% 5,8)$ \\
\hline \multicolumn{2}{|l|}{ Baba mesleği } \\
\hline Serbest meslek & $90(\% 37,2)$ \\
\hline İşçi & $78(\% 32,2)$ \\
\hline Memur & $62(\% 25,6)$ \\
\hline İşsiz & $8(\% 3,3)$ \\
\hline Çiftçi & $2(\% 0,8)$ \\
\hline Emekli & $2(\% 0,8)$ \\
\hline \multicolumn{2}{|l|}{ Akraba evliliği } \\
\hline Evet & $17(\% 7,0)$ \\
\hline Hayır & $225(\% 93,0)$ \\
\hline \multicolumn{2}{|l|}{ Aile tipi } \\
\hline Çekirdek & $205(\% 84,7)$ \\
\hline Geniş & $37(\% 15,3)$ \\
\hline \multicolumn{2}{|l|}{ Annenin sigara kullanma durumu } \\
\hline Hiç içmemiş & $216(\% 89,3)$ \\
\hline Halen içiyor & $10(\% 4,1)$ \\
\hline Gebelikte içmemiş şu an içiyor & $14(\% 5,8)$ \\
\hline Gebelikte içmiş şu an içmiyor & $2(\% 0,8)$ \\
\hline \multicolumn{2}{|l|}{ Annenin alkol kullanma durumu } \\
\hline Evet & $3(\% 1,2)$ \\
\hline Hayır & $239(\% 98,8)$ \\
\hline \multicolumn{2}{|l|}{ Gelir düzeyi } \\
\hline 1000 TL. ve altı & $102(\% 42,1)$ \\
\hline 1000 TL. üstü & $140(\% 57,9)$ \\
\hline \multicolumn{2}{|l|}{ Sosyal güvence } \\
\hline SGK & $200(\% 82,6)$ \\
\hline Yeşilkart & $30(\% 12,4)$ \\
\hline Yok & $7(\% 2,9)$ \\
\hline Özel sigorta & $5(\% 2,1)$ \\
\hline
\end{tabular}


Anneler gebelik sayılarına göre değerlendirildiğinde 2,1 \pm 1,2 (1-8 gebelik arası) olarak bulundu. Gestasyon yaşına göre bebeklerin 30'u prematüre $(\% 12,4), 212$ 'si $(\% 87,6)$ ise zamanında doğmuş veya postmatürdür. Doğumlarının \%50,4’ü normal spontan vajinal yolla (NSVD), \%49,6's1 ise sezeryan yöntemi $(\mathrm{C} / \mathrm{S})$ ile gerçekleşmiştir.

Bebeklerin yaş ortalaması 11,2 $\pm 7,3$ aydır. Bebeklerin \%46,7'si (113) kı, \%53,3'ü (129) erkek olarak dünyaya gelmiştir. Bebeklerin yaş dağılım aralığ 5 gün ile 24 ay arasında değişmektedir. Bebeklerin boy ortalaması 72,3 $\pm 10,1$; ağırlık ortalaması ise $9023,4 \pm 2572,8$ 'dir. Bebeklerin \%44,2'si (107) ilk bebek iken, \%84,3'ü (204) ilk 1 saat içinde anne sütü almıştır. 100 bebek (\%41,3) 3-6 ay arası anne sütü alırken, 40 bebeğin $(\% 16,5) 6$ aydan önce anne sütü kesilmiştir. Bebeklerin \%50,8'i (123) mama ile beslenmiş, $119(\% 49,2)$ bebeğe ise biberon verilmiştir. Bebeklerin \%25,6'sına (62) 6 aydan önce, $\% 51,2$ 'sine (124) ise 6 aydan sonra ek gida başlanmıştır. 100 $(\% 41,3)$ bebek ek gıdaya yoğurt ile, $36(\% 14,9)$ bebek çorba suyu ile, $31(\% 12,8)$ bebek ise meyve püresi ile başlamıştır. Bebeklerin çalışmanın yürütüldüğü andaki beslenme durumları Tablo 2'de görülmektedir.

Tablo 2. Bebeklerin şu anki beslenme durumları

\begin{tabular}{|c|c|c|c|c|c|c|c|c|}
\hline Yaş & Anne sütü & $\begin{array}{l}\text { Anne sütü } \\
+ \\
\text { Mama }\end{array}$ & $\begin{array}{l}\text { Anne sütü } \\
+ \\
\text { Ek gıda }\end{array}$ & Mama & $\begin{array}{l}\text { Mama } \\
+ \\
\text { Ek gida }\end{array}$ & Ek gida & $\begin{array}{l}\text { Anne sütü } \\
+ \text { Ek gıda } \\
+ \text { Mama }\end{array}$ & Toplam \\
\hline $0-6$ ay & 52 & 11 & 12 & 2 & 8 & 1 & 0 & 86 \\
\hline 13-18 ay & 0 & 1 & 30 & 0 & 18 & 3 & 1 & 53 \\
\hline 19-24 ay & 0 & 1 & 15 & 0 & 13 & 9 & 0 & 38 \\
\hline
\end{tabular}

Anneler anne sütü hakkındaki bilgilerini \%66,9 (162) oranında, ek gida hakkındaki bilgilerini ise \%62,4 (151) oranında sağlık çalışanlarından almışlardır. Bebeklerin \%90,1'inin (218) anne ve babasında kronik bir hastalık yok iken \%9,9'unda (24) kronik bir hastalık mevcuttur. Bebeklerin $\% 21,5$ 'i (52) solunum yolu enfeksiyonu, \%12,4'ü (30) ishal, $\% 3,7$ 'si (9) orta kulak enfeksiyonu, \%0,8'i(2) idrar yolu enfeksiyonu, \%2,9'u (7) ise mikst enfeksiyon geçirmiştir.

Anne eğitimi ile anne sütü hakkında bilgi $(\chi 2=35,536$; $\mathrm{p}=0,017)$, ek gida hakkında bilgi $(\chi 2=42,263 ; \mathrm{p}=0,003)$, anne sütü kesilme zamanı $(\chi 2=13,206 ; p=0,04)$ ve bebek kilo persentili $(\chi 2=49,777 ; p=0,007)$ arasında fark bulunmuştur. Annenin eğitim durumu arttıkça bebek kilo persentili de artmaktadır. Üniversite mezunu annelerin \%60'1 6 aydan önce anne sütünü kesmektedir. Annenin eğitim durumu arttıkça anne sütü ve ek gıda hakkındaki bilgileri sağlık çalışanlarından alma oranı artmaktadır. Üniversite mezunu annelerde bu oran $\% 75$ 'ler düzeyindedir. ANOVA testiyle farkların hangi gruptan kaynaklandığına bakıldığında ise anne eğitimi ile ek gida hakkında bilgi alınan yerlerde gruplar arası anlamlı fark bulunmuştur $(F=5,896 ; p<0,001)$. Anne eğitimi ile anne sütü hakkında bilgi alınan yerlere bakıldığında yine gruplar arası fark bulunmuş $(F=3,295 ; p=0,007)$ olup bu farkın sağlık çalışanları+basın ve sağlık çalışanları+çevre gruplarından kaynaklandığı tespit edilmiştir. Anne eğitimi ile anne sütü kesilme zamanı arasında gruplar arasında anlamlı fark bulunamamıştır $(\mathrm{F}=2,626 ; \mathrm{p}=0,078)$. Bebek kilo persentilinde ise fark yaratan grupların ilkokul ve üniversite mezunları olduğu gözlenmiştir $(\mathrm{F}=4,100 ; \mathrm{p}<0,001)$.

Mama kullanımı, biberon kullanımı, anne görüşü, ek gıda başlama şekli, ek gıda zamanı ve bebeklerin enfeksiyon durumu ile anne eğitimi arasında fark bulunamadı $(\mathrm{p}>0,05)$.

Bebeklerin boy-kilo persentillerine bakıldığında (Tablo 3) kilo açısından \%27,3'ünün 50-75 ve \%24,8'inin 25-50 persentiller arasında, boy açısından ise $\% 20,7$ oranında $25-50$ ve 50-75 persentiller arasında ve normal sinırlarda olduğu gözlendi. 3 persentilin altında kilo açısından 7 bebek var iken boy açısından 18 bebeğimiz bulunmaktadır. 97 persentil üstünde ise boy açısından 5, kilo açısından 10 bebek vardı.

Tablo 3. Bebeklerin boy ve kilo persentil değerleri

\begin{tabular}{lll}
\hline & \multicolumn{1}{c}{ Boy } & \multicolumn{1}{c}{ Kilo } \\
\hline 3 persentil ve altı & $\% 7,4(18)$ & $\% 2,9(7)$ \\
3-10 persentil & $\% 10,3(25)$ & $\% 6,2(15)$ \\
$\mathbf{1 0 - 2 5}$ persentil & $\% 19(46)$ & $\% 17,8(43)$ \\
$\mathbf{2 5 - 5 0}$ persentil & $\% 20,7(50)$ & $\% 24,8(60)$ \\
$\mathbf{5 0 - 7 5}$ persentil & $\% 20,7(50)$ & $\% 27,3(66)$ \\
$\mathbf{7 5 - 9 0}$ persentil & $\% 13,2(32)$ & $\% 14(34)$ \\
90-97 persentil & $\% 6,6(16)$ & $\% 2,9(7)$ \\
97 persentil ve & $\% 2,1(5)$ & $\% 4,1(10)$ \\
üstü & & \\
\hline
\end{tabular}

Persentillerin cinsiyete göre dağılımına baktığımızda (Tablo 4) ise 3 persentil altındaki bebeklerin boy açısından daha çok kız cinsiyette, kilo açısından ise erkek cinsiyette daha fazla olduğu görülmektedir. 97 persentil üstündekilere bakıldığında ise boy açısından kızların, kilo açısından ise erkeklerin önde olduğu gözlenmektedir.

Annelerin beslenme konusundaki görüşleri ile çocukların kilo persentil değerleri arasındaki ilişki Tablo 5'te gösterildi. Bebeğinin normal yediğini düşünen 164 annenin 87'sinin (\%53) bebeği 50 persentilin üstündedir. Bebeği 3 persentilin altında olan 7 annenin 6's1 ise $(\% 85,7)$ bebeğinin normal beslendiğini, 97 persentilin üstünde bebeği olan 10 annenin ise sadece 1'i $(\% 10)$ bebeğinin çok yediğini düşünmektedir. Bebeği 50 persentilin üstünde olan 107 annenin 15'i (\%14) bebeğinin az yediğini düşünmekte olup boy persentillerine bakıldığında bu değer \%18,4'tür (103/18).

Annelere göre bebeklerin yemek tercihlerine bakıldığında ise ek gida da alan 188 bebeğin $\% 25$ 'i (47) çorba ve yemek sularını, \%19,7'si (37) süt/süt ürünlerini, \%11,7'si (22) et/balı//tavuk/yumurta grubunu, \%6,9'u (13) ise meyve püresi/sularını tercih ettiği görülmektedir. 
Tablo 4. Bebeklerin boy ve kilo persentillerinin cinsiyete göre dağılımı

\begin{tabular}{lllll}
\hline & \multicolumn{2}{c}{ Boy } & \multicolumn{2}{c}{ Kilo } \\
\cline { 2 - 5 } 3 persentil & Kız & Erkek & Kız & Erkek \\
\cline { 2 - 5 } $\begin{array}{l}\text { ve altı } \\
\mathbf{3 - 1 0} \\
\text { persentil } \\
\mathbf{1 0 - 2 5} \\
\text { persentil }\end{array}$ & $10(55,5)$ & $8(44,5)$ & $3(42,8)$ & $4(57,2)$ \\
$\begin{array}{l}\mathbf{2 5 - 5 0} \\
\text { persentil } \\
\mathbf{5 0 - 7 5}\end{array}$ & $18(39,1)$ & $28(60,9)$ & $15(34,9)$ & $28(65,1)$ \\
persentil & $24(48)$ & $26(52)$ & $29(43,9)$ & $37(56,1)$ \\
$\begin{array}{l}\mathbf{7 5 - 9 0} \\
\text { persentil } \\
\mathbf{9 0 - 9 7} \\
\text { persentil } \\
\mathbf{9 7}\end{array}$ & $21(63,6)$ & $11(33,3)$ & $19(55,9)$ & $15(44,1)$ \\
$\begin{array}{l}\text { persentil ve } \\
\text { üstü }\end{array}$ & $4(37,5)$ & $10(62,5)$ & $4(57,1)$ & $3(42,9)$ \\
\hline
\end{tabular}

\section{TARTIŞMA}

Dünya Sağlık Örgütü tarafından ilk 6 ay sadece anne sütü önerilmekte olup (4) ilk 6 aydaki anne sütü ile bağ 1 şıklık sistemi uyarılmakta, aşılara daha iyi yanıt verilmesine yardımcı olunmakta ve gelişmekte olan ülkelerde bebek ölümlerinin iki ana nedeni olan ishal ve solunum yolu enfeksiyonlarına karşı korunma sağlanmaktadır (2). Anne sütü ile beslenen bebeklere eksik kalan besin gereksinimini tamamlamak üzere 6 aydan itibaren tamamlayıcı besinler başlanmalı ve 2 yaşına kadar anne sütüne devam edilmelidir (3).

İlk 6 ay sadece emzirilen çocuk oranını \% 80'e çıkartmak, 6.aydan sonra bebeklerin \%100'üne uygun ek gıda başlanıyor olmasını sağlamak, ilk 3 ay ek gida başlanan çocuk oranını $\% 10$ 'un altına indirmek, uygun ek gida almakta olan 6 ay üzerindeki çocukların \%90'ının iki yaşına dek emziriliyor olmasını sağlamak ve birinci basamakta görevli personelin \%100'üne emzirmenin desteklenmesi ve sürdürülmesi için uygulamaya yönelik eğitim vermek Türkiye Cumhuriyeti (T.C.) Hükümeti-UNICEF 2001-2005 ana uygulama planında hedefler arasında yer almıştır (9).

Tablo 5. Annelerin beslenme konusundaki görüşleri ile çccukların kilo persentil değerleri arasındaki ilişki

\begin{tabular}{|c|c|c|c|c|c|c|c|c|c|}
\hline \multirow{6}{*}{$\begin{array}{l}\text { Anne } \\
\text { görüşüu }\end{array}$} & \multicolumn{9}{|c|}{ Kilo persentil } \\
\hline & & $<3$ & $3-10$ & $10-25$ & $25-50$ & $50-75$ & $75-90$ & $90-97$ & $>97$ \\
\hline & Bilmiyorum & 0 & 1 & 0 & 4 & 1 & 3 & 0 & 1 \\
\hline & Az yer & 1 & 3 & 18 & 11 & 9 & 6 & 1 & 0 \\
\hline & Normal & 6 & 9 & 24 & 38 & 50 & 24 & 5 & 8 \\
\hline & Çok yer & 0 & 2 & 1 & 7 & 6 & 1 & 1 & 1 \\
\hline Toplam & & 7 & 15 & 43 & 60 & 66 & 34 & 7 & 10 \\
\hline
\end{tabular}

Yapılan çalışma ve sistematik derlemeleri özetleyen bir çalışmada ilk 5 ay bebeklerin \%90'nın sadece anne sütü alması ve \%99'unun 12. aya kadar emzirilmeye devam edilmesi durumunda dünyada 5 yaş altı çocuk ölümlerinin $\% 13$ azalacağı tahmin edilmektedir(10).

Norveç, Amerika Birleşik Devletleri, Meksika, İtalya ve Avustralya'da yapılan çalışmalarda altıncı ayda tek başına anne sütüyle beslenme sıklığı sırasıyla \%7,0; \%14,0;\%24,0; \%42,3 ve $\% 50,0$ olarak bildirilmiştir (11-15). TNSA-2008 verilerine (16) göre bizim ülkemizde altıncı ayda tek başına anne sütüyle beslenme sıklığı \%41,6 olarak bulunmuş olup bizim çalışmamızda ise \%60,4 'tür ve 2008 verilerinden daha yüksektir. Bu da bize ülkemizde anne sütünün öneminin yıllar geçtikçe daha net anlaşıldığını ancak daha kat etmemiz gereken çok yolumuz olduğunu göstermektedir.

Bülbül ve arkadaşlarının yaptığı çalışmada anne sütü alma oranı 0-3 ay arasında \%32 iken 3-6 ay arasında \%20 olarak tespit edilmiştir(17). Bağ ve arkadaşlarının çalışmasında 1,3 ve 6. aylarda ise $\% 51, \% 28,7$ ve $\% 17,3$ olarak bulunmuştur (18). Ülkemizde yapılan 5003 annenin katıldığı bebekleri besleme uygulamaları ve bu konudaki inanışların değerlendirildiği bir çalışmada doğumdan sonra sadece anne sütü alan bebekler $\% 97$ iken, ikinci ayda bu değerin \%81,5'e, dördüncü ayda \%46,2'ye düştüğü, altıncı ayda ise annelerin sadece $\% 8,7$ 'sinin anne sütü vermeye devam ettiği görülmüştür (19). Çalışmamızdaki bebeklerin ise sadece \%41,3'ü 3-6 ay arası anne sütü alırken, bebeklerin \%16,5'inde 6 aydan önce anne sütü kesilmiştir. Sütten kesme nedenlerinin başında sütün yetmemesi $(n=34)$, bebeğin emmek istememesi, ek besine geçme $(n=8)$ ve bırakma yaşının gelmesi ( $\mathrm{n}=7$ ) gibi nedenler yer almaktadır. Bebek yaşı ile sadece anne sütü alma, anne sütü kesilme zamanı ve emzirmeme nedeni arasında anlamlı ilişki bulunmuştur $(\mathrm{p}=0,004 ; \mathrm{p}=0,017 ; \mathrm{p}<0,001)$. Literatür ile kıyaslandı̆̆ında anne sütü alma süresi bizim çalışmamızda diğer çalışmalara göre daha yüksek olarak bulunmuştur. Ancak bu değerler yine de istenen düzeyde değildir.

Çalışmamızdaki annelerin \%84,3'ü doğumdan sonra ilk bir saat içinde bebeklerini emzirmişlerdir. Doğumdan sonra ilk bir saat içinde emzirme oranını Özenç (20) \%55,4; Taş (21) \%44, Yiğitbaş ve arkadaşları (22) \%58,9; Eker ve arkadaşları (23) ise $\% 69,9$ olarak açıklamışlardır. Kayseri’de 19 sağlık ocağında yapılan bir çalışmada ise annelerin $\% 80,5$ 'i ilk bir saat içinde bebeklerini emzirmiş olup bizim değerlerimiz bu çalışmadan da yüksek olmakla birlikte benzerlik göstermektedir. Bizim çalışmamızdaki değerin yüksek olması devletin yaptığı kamu spotları ve reklamlar sayesinde halkın anne sütü konusunda daha çok bilinçlenmesinden kaynaklanıyor olabilir.

62 bebeğimiz $(\% 25,6) 6$ aydan önce ek besine geçiş yaparken, 123 bebeğimiz $(\% 50,8)$ ek besine 6 aydan sonra geçmiştir. Küçük ve Göçmen tarafından yapılan çalışmada ek gıdalara başlama zamanı ortalama 5,8 $\pm 0,85$ ay olarak bulunmuş ve bebeklerin \%23,2'si ek gidaya altıncı aydan önce başlamıştır. Aynı çalışmada 6-12 ay arası bebeklerin \%72'si, 13-18 ay arası çocukların \%56'sı, 19-24 ay arası çocukların ise \%33,3'ü anne sütü almaya devam etmektedir (24). Kayseri'de 2005 yılında yapılan bir çalışmada altı ay ve daha küçük bebeklerin \%50,2'sinin sadece anne sütü ile beslenmiş olup, bebeklerin \%80,3'üne altı aydan önce ek besin başlandığı 
bulunmuştur (25). TNSA-2008 verilerine göre bebeklerin $\% 8{ }^{\prime} \mathrm{i}$ 6 aydan önce anne sütü yanında ek besin alırken, 6-9 aylar arasında bu değer \%67,5'tir (16). Bizim çalışmamızda ise 6 aydan önce anne sütü+ek besin alma sıklığı \%13,9; 7-12 aylar arasında ise \%66,1'dir. Bu durumu TNSA-2008 verileriyle kıyaslayacak olursak 6.aydan önce ek besine geçme sıklığında artış olduğunu söyleyebiliriz. Elimizdeki veriler 1şı̆̆ında ek besine geçme zamanı konusunda halkın bilgilendirilmeye daha çok ihtiyacı olduğu söylenebilir.

Burdur'da 2009 yılında Çatak ve arkadaşları tarafından yapılan çalışmada toplamda altı aydan küçük bebeklerin $\% 52,9$ 'unun sadece anne sütü almakta iken, \%6,7'sinin emzirilmeden kesilmiş olduğu, bebeğin yaşına göre değerlendirildiğinde ise iki aydan küçük bebeklerin \%96,3'ünün, 2-3 aylık bebeklerin \%67,9'unun, 4-5 aylık bebeklerin ise \%26,1'inin sadece anne sütü ile beslendikleri tespit edilmiştir. Aynı çalışmada 4-5 aylık bebeklerin \%52,3'üne anne sütüne ilaveten ek besin başlandığ 1 bulunmuştur (18). Ünalan ve arkadaşlarının çalışmasında ek besine 6.aydan önce geçme oranı \%58 olarak bulunmuştur (26). Bizim çalışmamızda 6.aydan önce ek besine geçme oranları diğer çalışmalara göre daha düşük olduğu için annelerin bu konuda da bilinçlendiğini söyleyebiliriz.

Araştırmalarda ilk 6 ay tek başına anne sütü alan bebeklerde ilk 3-4 ay tek başına anne sütü alan bebeklere oranla daha az diyare ve solunum hastalıkları görüldüğü bildirilmektedir $(27$, 28). Gelişmiş ülkelerde tamamlayıcı besine 4-6 ayda başlanmasını önerenler ile 6. aydan sonra başlanmasını öneren ülkelerdeki bebeklerin sağlık durumları arasında bir kıyaslama yapıldığında 6 ay tek başına anne sütü alan bebeklerin solunum yolu enfeksiyonuna yakalanma oranları 4-6 ay arasında tamamlayıcı besinlere başlayan bebeklere göre daha düşük bulunmuştur (28). Bizim çalışmamızda da bebeklerdeki enfeksiyon geçirme oranları ile anne sütü kesilme zamanı, ek gıdaya başlama zamanı, mama ve biberon kullanma oranları karşılaştırıldığında istatistiksel olarak anlamlı fark bulunamamış olup $(p>0,05) \quad 6$ aydan önce anne sütü kesilenlerde enfeksiyon oranları daha yüksek tespit edilmiştir. 6 aydan önce anne sütü kesilen bebeklerin \%64,2'sinde ishal, \%35'inde solunum yolu enfeksiyonu, \%33,3'ünde mikst enfeksiyon, \%100'ünde de idrar yolu enfeksiyonu görülmüştür. Anne sütü bebekte gelişebilecek diyare, solunum yolu enfeksiyonları, astım, orta kulak iltihabı gibi sağlık problemlerinin görülme sıklığını ve şiddetini azaltmaktadır. Çalışmamızda 6 aydan önce anne sütü kesilen bebeklerdeki enfeksiyon oranları da bu görüşü desteklemektedir.

İyi bir tamamlayic1 besin enerji, protein, vitamin ve minerallerce zengin olmalı, temiz ve güvenli olmalı, çok fazla sıcak ya da soğuk olmamalı, çok tuzlu ve baharatlı olmamalı, bebek tarafindan kolay yenebilmeli ve sevilmeli, bölgesel olarak ulaşılabilir olmalı, satın alınabilir olmalı, hazırlanması kolay ve kıvamı uygun olmalıdır (29). Motee ve arkadaşlarının yaptığı çalışmada annelerin \%69,2'si beslenme döneminde hem ev yapımı yemeği hem de satın alınabilir mısır gevreği veya hazır konserve, \%66,9'u beslenmeye meyve veya sebze püresiyle başladıklarını belirtmişlerdir. Çalışmaya katılanların \%93,5'i ev yapımı yiyeceklerin daha taze ve hijyenik olması nedeniyle bu gidaların daha fazla tercih edildiğini belirtmişlerdir. \%86,4'ü ev yapımı gıdaların besleyici özelliğinin daha fazla olduğunu, \%84,9'u ise ev yapımı gıdalarla daha dengeli beslenildiğini belirtmişlerdir (30). İsviçre'de yapılan bir çalışmada anneler ev yapımı gıdaları taze, besleyici ve hijyenik olduğu için daha çok tercih ettiklerini belirtmişlerdir (31). Çatak'ın çalışmasında ise yaşı 6 aydan küçük olup halen emzirilmekte olan bebeklere en fazla verilen ek besinler sirasiyla meyve suyu $(\% 55,1)$, süt $(\% 48,7)$ ve hazır mama $(\% 40,3)$ iken yaşı 6 aydan küçük olup emzirilmeyen bebeklere en fazla verilen ek besinler ise sirasiyla hazır mama $(\% 92,3)$, tahıllı yiyecekler $(\% 61,5)$ ve süt $(\% 30,8)$ olarak belirtilmiştir (18). Çalışmamızda bebeklerin \%41,3'ü ek gıdaya yoğurt ile, \%14,9'u çorba suyu ile, \%12,8'i ise meyve püresi ile başlamıştır. Türkiye'de anneler daha çok bebeklerini kendi mayaladıkları yoğurt ile beslemektedirler.

Ludvigsson tarafından yapılan çalışmada anneye doğum öncesi ve sonrasında sağlık profesyonelleri tarafindan verilen eğitimin anne sütü ile beslenme oranını arttırdığı ve erken ek gıda başlanmasından kaçınılmayı sağladığı ortaya konulmuştur (33). Eker ve Yurdakul'un Mersin'de bebek dostu hastanelerde yaptıkları çalışmada ise annelerin gebelik döneminde bebek beslenmesi ve emzirme konusunda bilgi alma oranının \%55,4; postpartum dönemde ise $\% 68,5$ olduğu gözlenmiștir. Anneler bu bilgiyi \%47,8 ebe/hemşirelerden almaktadırlar (23). Ünsal ve arkadaşlarının 5003 anne üzerinde yaptıkları bir çalışmada annelerin \% 62,2'sinin sağlı personeli, \% 13,8'inin ebeveynleri, \% 11,5'inin medya ve \% 7,5'inin arkadaşları tarafindan bilgilendirildikleri belirtilmiştir (19). Bizim çalışmamızda anneler anne sütü hakkındaki bilgilerini \%66,9; ek gıda hakkındaki bilgilerini ise $\% 62,4$ sağlık çalışanlarından almış olup sonuçlarımız diğer çalışmalarla benzerdir. Sağlık profesyonelleri tarafindan emzirme konusunda anneye sağlanan destek, annenin bebeğini sadece anne sütü ile besleme süresini önemli oranda arttırmaktadır (32). Bizim çalışmamızda annenin eğitim düzeyi ile anne sütü hakkında bilgi, ek gida hakkında bilgi, anne sütü kesilme zamanı ve bebek kilo persentili arasında fark bulunmuştur $(\mathrm{p}<0,05)$. Annenin eğitim durumu arttıkça sağlık çalışanlarından bilgi alma oranları ve bebeklerin kilo persentilleri artmıs ancak eğitimli annelerin anne sütünü kesme zamanları azalmıştır. Üniversite mezunu annelerin \%60’1 6 aydan önce anne sütünü kesmişlerdir. Bunun nedeni de eğitimli kesimin daha çok iş yaşamında olması ve nispeten doğumdan sonra çalışmaya daha erken başlaması olabilir. Bu konuda devletimiz tarafından çalışan ve emziren annelere destek olunmalı, kolaylıklar sağlanmalı ve bu durumla ilgili yasalar çıkarılarak anne sütü, çalışan annelerde de teşvik edilmelidir. Literatürde de görüldüğü üzere sağlık personeline anneleri bilgilendirme konusunda önemli görevler düşmektedir.

Anne-baba mesleği, gelir düzeyi, sosyal güvence, akraba evliliği, annenin sigara kullanması gibi etkenler de çalışmamızda ailenin sosyoekonomik düzeyini belirleyerek bu düzeyin de beslenme alışkanlıkları üzerine yansımasını incelemek açısından sorgulanmış ancak istatistiksel olarak anlamlı bir fark bulunamamıştır $(\mathrm{p}>0,05)$. Ailenin sosyoekonomik düzeyi ve annenin sigara kullanma durumunun bebeğin beslenme alışkanlıkları üzerinde olumlu veya olumsuz katk1s1 yoktur.

Çalışmada dikkat çeken bir diğer nokta ise annelerin bebeklerinin beslenme durumlarını değerlendirme konusunda doğru değerlendirme yapamamaları olmuştur. Bebeği 3 persentilin altında olan annelerin \%85,7'sinin bebeğinin normal beslendiğini, 97 persentilin üstünde bebeği olan annelerin ise sadece \%10'unun bebeğinin çok yediğini düşünmesi bu görüşümüzü desteklemektedir. Bu sonuç da Türk toplumunun yapısına bağlanabilir. 


\section{SONUÇ}

Annelerin anne sütü ve tamamlayıcı beslenme konusundaki bilgi düzeyleri ne kadar iyi olursa toplumun da bilgi düzeyi o kadar artış gösterecek ve davranışlarına yansıyacaktır. Sağlıklı nesiller için sağlıklı beslenmenin temelleri küçük yaşlarda atılmalıdır. Bunun içindir ki, anneyi gebeliğinden bu yana izleyen ve bebeği de ilk gören yerlerden biri olan birinci basamağa anne sütü ve ek gida hakkında annelerin bilgilendirilmesi ve bilinçlendirilmesi konularında önemli görevler düşmektedir. Çalışmamızda eğitimli annelerin emzirmeyi daha erken dönemde kestikleri gözlenmiş olup, eğitimli annelerin anne sütü vermeleri gereken dönemde işe başladıkları sonucuna varılmıştır. $\mathrm{Bu}$ yüzden de devletimiz tarafindan çalışan ve emziren annelere destek olunmalı, kolaylıklar sağlanmalı ve bu durumla ilgili yasalar çıkarılarak, mesai saatlerinde düzenlemeler yapılarak anne sütü, çalışan annelerde de teşvik edilmelidir.

\section{KAYNAKLAR}

1. Coşkun T. Anne Sütü ile beslenme. İçinde: Tunçbilek E, editör. Çocuk Sağlığı Temel Bilgiler. İkinci baskı. Ankara: Yeniçağ Basın Yayın San. Ve Tic.Ltd.Şti. sf. 19-46

2. WHO Global Strategy for Infant and Young Child Feeding. Geneva: WHO, 2003.

3. Ankara Halk Sağlığı Müdürlüğü, Çocuk, Ergen, Kadın, Üreme Sağlığ1 Hizmetleri Şube Müdürlüğü, Tamamlayıcı Beslenme El Kitabı, 2011 Ankara.

4. Infant and young child feeding. A tool for assessing national practices, policies and programmes. WHO 2003 http://www.who.int/childadolescenthealth/New_Publications/N UTRITION/icyf.pdf (erişim tarihi: 21.03.2016)

5. Complementary feding report of the global consultation Summary of guiding principles. WHO Geneva, 10-13 December 2001http://www.who.int/childadolescenthealth/New_Publicatio ns/NUTRITION/Complementary_Feeding.pdf(erişim tarihi: 21.03.2016)

6. Özalp, I., Çoşkun, T., (1988). Büyümenin İzlenmesi, Çocuk Sağlı̆̆ı Temel Bilgiler (Ed.E.Tunçbilek), Ankara SSYB Matbaasi.

7. Yüce, A., Koçak, N., (1996). İshalli Çocuk Beslenmesi, Katk1 Pediatri Dergisi, 17:2:335-340. GÜ, Gazi Eğitim Fakültesi Dergisi, Cilt 24, Say1 3 (2004) 81-100 Sifır-Üç Yaş Grubunda Çocuğu bulunan Annelerin Beslenme ve İshal konusunda Bilgi ve Davranışlarının İncelenmesi.

8. Yağcı R.V. Klinik Pediatri Dergisi Çocuklarda Beslenme Özel Eki-2012.

9. Ulusal Gıda Ve Beslenme Stratejisi Çalışma Grubu Raporu. Ankara, 2001.http://ekutup.dpt.gov. tr/gida/strateji.pdf)

10. Jones G, Steketee RW, Black RE, Bhutta AZ, Morris SS. How many child deaths can we prevent this year? Lancet 2003;362:6571

11. Lande B, Andersen LF, Baerug A, et al. Infant feding practices and associated factors in first six months of life: the Norvegaian infant nutrition survey. Acta Paediatr 2003;92:61-152.

12. Li R, Darling N, Maurice E, Barker L. Breastfeeding rates in the United Sates by characteristics of the child, mother, or family. The 2002 National Immunization Survey. Pediatrics 2005;11:731.

13. Gonzalez-Cassio T, Moreno-Macias H, Rivera JA, et al. Breastfeeding practices in Mexico: results from the Second National Nutrition Survey 1999. Salud Publica Mex 2003;45:89-477.

14. Betrini G, Perugi S, Dani C, Pezzati M, Trochini M, Rubaltelli FF. Maternal education and the incidence and duration of breastfeeding: A prospective studay. J Pediatr Gastroent Nutr 2003;37:52-477.

15. Donath SM, Amir LH. Breastfeeding and the introduction of solids in Australian infants: data from the 2001 National Health Survey. Aust NZJ Public Health 2005;29:5-171.)

16. Hacettepe Üniversitesi Nüfus Etütleri Enstitüsü (2009) Türkiye Nüfus ve Sağlık Araştırması, 2008. Hacettepe Üniversitesi Nüfus Etütleri Enstitüsü, Sağlık Bakanlığı Ana Çocuk Sağlığı ve Aile Planlaması Genel Müdürlügüu, Başbakanlık Devlet Planlama Teşkilatı Müsteşarlığı ve TÜBİTAK, Ankara, Türkiye.

17. Bülbül S., Kılınçkaya M.F. 0-2 yaş grubu bebeklerin anne sütü ile beslenme durumları ve etkileyen faktörler. KÜ. Tıp Fak. Derg. 2013; 15 (1).

18. Çatak B, Sütlü S, Kılınç AS ve ark. Burdur ilinde bebeklerin emzirilme durumu ve beslenme örüntüsü. Pamukkale Tip Dergisi. 2012;5(3):115-122.

19. Ünsal H, Atlıhan F, Özkan H ve ark. Toplumda anne sütü verme eğilimi ve buna etki eden faktörler. Çocuk Sağlığı ve Hastalıkları Dergisi 2005; 48: 226-233.

20. Özenç Ö. Balıkesir İlinde 0-12 Aylık Çocuğu Olan Annelerin Süt Çocuğu Beslenmesi İle İlgili Bilgi Ve Davranışlarının Belirlenmesi. 13.Ulusal Neonatoloji ve Yenidoğan Hemşireliği Kongresi. Kongre Kitab1. 2005. s/516.

21. Taş F, Erdem H. Konya Merkez 15 Nolu Sağlık Ocağı Bölgesindeki Bebeklerin Emzirilme Durumları. 13.Ulusal Neonatoloji ve Yenidoğan Hemşireliği Kongresi. Kongre Kitabı. 2005. s/506.

22. Yiğitbaş Ç, Kahriman İ, Yeşilçiçek $K$ ve ark. Trabzon İl Merkezindeki Hastanelerde Doğum Yapan Annelerin Emzirme Tutumlarının Değerlendirilmesi. 13.Ulusal Neonatoloji ve Yenidoğan Hemşireliği Kongresi. Kongre Kitabı. 2005. s/483.

23. Eker A, Yurdakul M. Annelerin bebek beslenmesi ve emzirmeye ilişkin bilgi ve uygulamaları. Mersin Üniversitesi Sağlık Yüksekokulu. Sürekli Tıp Eğitimi Dergisi. 2006; 15(9): 158-163.

24. Küçük Ö, Göçmen AY. Çocuk Polikliniğine Başvuran 6-24 Ay Arası Sağlam Çocukların Değerlendirilmesi. Bakırköy Tıp Dergisi. 2012; 8(1): 28-33.

25. Tuna R. Bebeklerde ishal morbiditesi ile beslenme ve büyüme etkileşimleri. Yüksek Lisans Tezi, Erciyes Üniversitesi Halk Sağlığı Anabilim Dalı, Kayseri, 2005.

26. Samlı G, Kara B, Ünalan PC, Samlı B, Sarper N, Gökalp AS. Annelerin emzirme ve süt çocuğu beslenmesi konusundaki bilgi, inanış ve uygulamaları: niteliksel bir araştırma. Marmara Med J 2006; 19:13-20.

27. Kramer MS, Guo T, Platt RW, Sevkovskaya Z, Dzikovich I, Collet JP, et al. Infant growth and health outcomes associated with 3 compared with 6 months of exclusive breastfeeding. Am J Clin Nutr 2003;78:291-5.

28. Chantry C, Howard C, Auinger P. Full breastfeeding duration and associated decrease in respiratory tract infection in US children. Pediatrics 2006;117:425-32.

29. Ilgaz Ş. Tamamlayıcı Beslenme Sağlık Çalışanları için Rehber Kitap. 2009; 8.

30. Motee A, Ramasawmy D, Pugo-Gunsam P, Jeewon R An Assessment of the Breastfeeding Practices and Infant Feeding Pattern among Mothers in Mauritius, J Nutr Metab. 2013; 2013: 243852.

31. Dratva J, Merten S, Ackermann-Liebrich U. The timing of complementary feeding of infants in Switzerland: compliance with the Swiss and the WHO guidelines. Acta Paediatrica. 2006;95(7):818-825.

32. Gartner LM, Attitudes and practices of family paediatricians in Italy regarding infant feeding. Acta Paediatr. 2012 Oct;101(10):1063-8.

33. Ludvigsson JF. Breastfeeding in Bolivia, information and attitudes. MC Pediatr. 2003;3:4. 


\section{EK: Beslenme Anketi}

1- Anne yaş1:.........

2-Anne eğitimi: 1. ilkokul 2.ortaokul 3.lise 4.üniversite 5.okuma-yazma yok

3-Anne mesleği: 1.ev hanımı 2.memur 3.serbest meslek

4-Gestasyon yaş1: 1.preterm 2.term/postterm

5-Gebelik sayıs1:..........

6-Gebelikte veya doğumda problem olma durumu: 1.evet 2.hayır

7-Doğum şekli: 1.normal doğum 2.sezaryan

8-Annenin sigara kullanma durumu: 1.gebelikte içmiş halen içiyor $\quad$ 2.gebelikte içmiş şu an bırakmış 3.hiç içmemiş 4.gebelikte içmemiş şu an içiyor

9-Annenin alkol kullanma durumu: 1.evet 2.hayır

10-Gelir durumu: 1.1000 TL.ve altı 2.1000 TL.üstü

11-Sosyal güvence: 1.SGK 2.yeşilkart 3.yok 4.özel sigorta

12-Akraba evliliği mi?: 1.evet 2.hayır

13-Aile tipi: 1.çekirdek 2.geniş

14-Babanın mesleği : 1.işçi 2.memur 3.çiftçi 4.işsiz $\quad$ 5.serbest meslek

15-Bebeğin yaşı:.

16-Bebeğin cinsiyeti : $1 . \mathrm{k1z} \quad$ 2.erkek

17-Bebeğin boyu:.

18-Bebeğin ă̆ırlı̆̆1:

19-Bebeğin ilk bebek olma durumu: 1 .evet $\quad$ 2.hayır

20-İlk anne sütünün ne zaman verildiği: $1.1 \mathrm{klk} 1$ saat içinde $\quad 2.1 \mathrm{lk} 1$ saatten sonra

21-Tek başına anne sütünün ne kadar süre ile kullanıldığı: $\quad 1.3$ aydan az $\quad 2.3-6$ ay $\quad 3.6$ aydan fazla

22-Emzirmeme nedeni?: 1.sütün yetmemesi 2.bebeğin emmek istememesi 3.bebeğin hastalığı 4.annenin hastalığ1 5.ek besine geçme 6.gebelik 7.işe başlama $\quad$ 8.meme ucu/göğüs sorunu 9.bırakma yaşının gelmesi

23-Anne sütünün ne zaman kesildiği: $\quad 1.6$ aydan önce $\quad 2.6-12$ ay arası $\quad 3.12-24$ ay aras1

24-Emzirmenin bebeğe yararı olup olmadı̆̆ı: 1.var 2.yok 3.bilmiyorum

25-Şu anda ne ile beslendiği?: 1 .sadece anne sütü 2.anne sütü+mama $\quad 3$.anne sütü+ek besin 4. mama+ek besin

26-Mama verildi mi?: 1 .evet 2.hayır

27-Mama verilme nedeni?: 1.bebeğin doymaması $\quad$ 2. bebeğin sık uyanması $\quad 3$.annenin ilaç kullanması 4.annenin hamile kalması $\quad$ 5.çevre baskısı

28-Ek gıdalara başlama zamanı: 1.6 aydan önce 2. 6.aydan sonra 
29-Ek gıdalara ilk ne ile başlandığı: 1.yoğurt 2.çorba suyu 3.meyve püresi

30-Bebeğe biberon verildi mi?: 1.evet 2.hayır

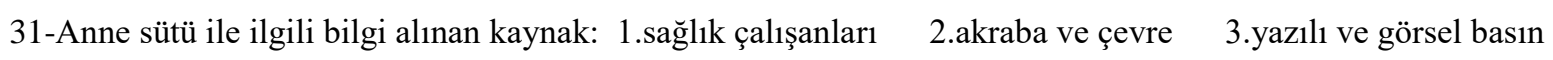

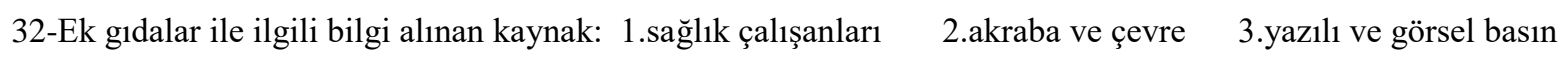

33-Çocukların yemek tercihleri: 1.süt/süt ürünleri 2.et,balık,tavuk,yumurta 3.meyve püresi/suları 4.çorba/yemek suyu ve yemek 5.tahill yiyecek 6.tatl yiyecekler

34-Annenin çocuk hakkındaki görüşü: 1.az yiyor 2.normal yiyor $\quad 3$.çok yiyor

35-Bebeğin enfeksiyon geçirme durumu: 1 .ishal $\quad$ 2.solunum yolu enf. $\quad 3$. orta kulak enf. 4.yok

36-Anne ve babada ilaç kullanmayı gerektiren sistemik hastalık öyküsü: 1.var 2.yok 